\title{
千葉市木戸作遺跡縄文後期貝層出土ウマ遺存体の年代の再評価 —伴出哺乳動物骨のフッ素分析より——
}

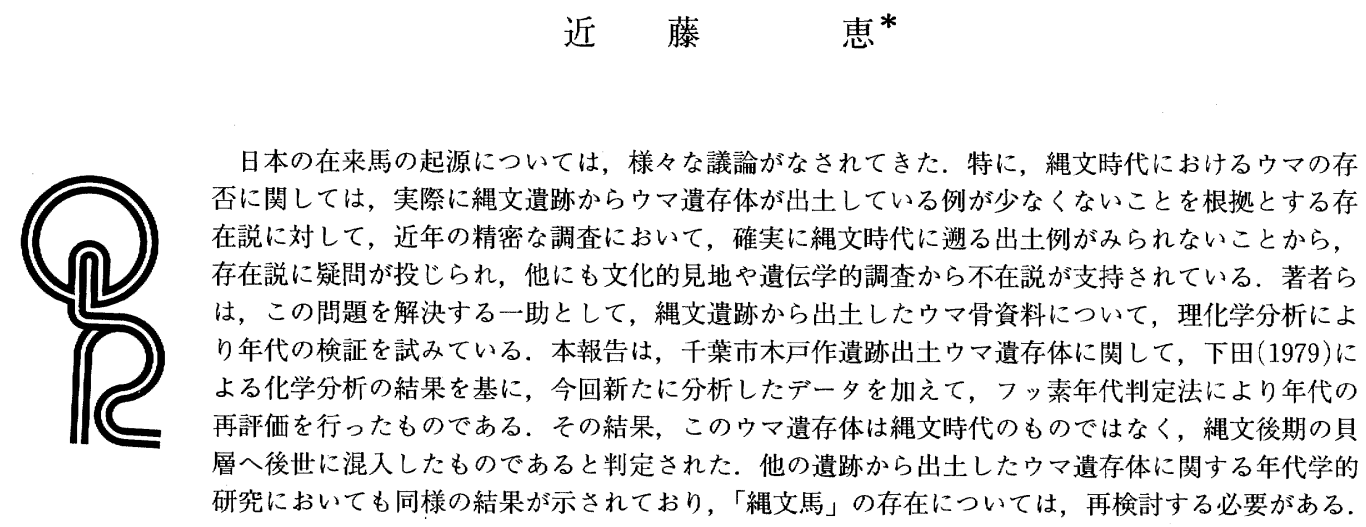

キーワード : 木戸作遺跡, 縄文貝塚, ウマ遺存体, フッ素年代判定法, 後世の混入

\section{I. はじめに}

わが国にいつ頃からウマが存在していたかという問題 については，これまで様々な議論がなされてきた．明治 時代以来, 日本列島各地の縄文時代の貝塚からウマ遺存 体の出土が報告されてきたことから，縄文時代にウマが 存在していたことを認める立場がある(大給, 1934； 長谷部, 1943 ; 最上, 1957 ; 樋口, 1959 ; 酒詰, 1961 ; 芝田, 1969 ; 直良, 1971 ; 加茂, 1973 ; 江坂, 1990 ; 国 分, 1992 ほか)。一方, 近年, 精度の高い大規模な発掘 調查の数が著しく増加してきたのに反して，縄文時代の 文化層からウマ遺存体の出土数が激減していることか ら，従来の出土記録の中には疑わしいものが含まれてい る可能性の高いことが示唆され, 縄文時代におけるウマ の存在を疑問視する見解も述べられるようになってきた (西中川ほか, 1989, 1991 ; 松井, 1991，1992 ほか). また，遺伝学的調查（野澤，1983）や文化的見地（佐

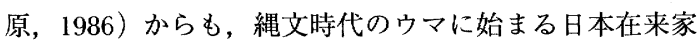
畜馬の歴史・系統論（例えば，林田，1978）を支持しな い考えが出されている.
著者ら（近藤ほか，1991，1992）はこれまでに，千葉 県野田市大崎貝塚や鹿児島県出水市出水貝塚などの縄文 遺跡から出土したウマ骨の年代学的研究を行ってきた が，それらのウマ骨が縄文時代のものではなく，後世の 混入物であることを示した．他の縄文貝塚でも，こうし た後世のウマ遺存体の混入が自然科学的分析によって指 摘された例が報告されている（松浦，1976，1978）こと から，著者らは縄文時代にウマが存在していたか否かに ついては再検討が必要と考えている.

千葉市椎名崎町 895 番地打よびその周辺に所在する 木戸作遺跡では，1975 76 年にかけて財団法人千葉県 文化財センターによる発掘調査が箺施されたが（郷田・ 栗本, 1979), その際, 縄文時代後期初頭の遺物ととも にウマの遺存体が採り上げられた。これは, 最近の調查 によるものとしては，稀な「縄文馬」産出例である，下 田(1979)は，このウマ遺存体の一部を含む本遺跡出土哺 乳動物骨について，フッ素拉よびマンガン含量の測定を 行い, ウマは後の時代の混入によるものであることが一 つの可能性として考えられると述べている. しかし，下 田(1979)の報告からは，ウマ資料に対して比較基準資料 
となる他の動物骨の測定点数がややそしいので, 明確な 結論を得るのは難しい，そこで本研究では，フッ素年代 判定 (Oakley, 1980 ; 松浦, 1984 ほか) に必要な比較 デー夕を充実するため, 新たに本遺跡の縄文後期貝層出 土骨資料のフッ素分析を行い, 改めてウマの年代に関す る再評価を試みた。

\section{II. 木戸作遺跡の概要とウマ遺存体の産出状況}

千葉市木戸作遺跡は, 全層位から単一型式土器（堀之 内式）が出土する点で特殊な縄文時代後期の貝塚である (郷田・栗本, 1979). 1975 76 年に行われた 7 カ所 （第 1～第 7）の斜面貝塚を中心とした発掘調查によ り, 陸生哺乳動物遺存体が, 最少個体数で 94 点（ヒ上 を除く）と豊富に出土した。これらの遺存体にはノウサ ギ, タヌキ, キッネ, ニホンオオカミ, イヌ, アナグ マ, ニホンジカ, イノシシ, ウマの 9 種が認められた (諏訪ほか，1979). ウマは第 2 および第 5 貝塚から得 られた。第 2 貝塚では，ほぼ完全な右膝蓋骨と左膝蓋 骨片が貝層下部から出土し，第 5 貝塚では，1個体に属 すると考えられる身体各部の骨が，10 $\mathrm{m}$ 以上離れて散 乱した状態で出土した.

第 5 貝塚出土のウマについては，前述のように，下 田(1979)のフッ素およびマンガン含量の測定により，よ り新しい時代の遺存体が混入したものであることが一つ の可能性として挙げられたが, 郷田・栗本(1979: p. 237，239)によれば，第 5 貝塚は「発掘に着手する時点 で，すでにかなりの貝殼が地表に散乱し，また抜根によ ると思われる穴が多数みられたことから，かなりの攪乱 を受けていることが予測された」ということであるの で， ウマが後世のものである可能性は少なくないと推定 される。

一方, 第 2 貝塚出土のウマは, 諏訪ほか (1979:p. 462)では，「貝層下部から出土していること抢よび第 5 貝塚の馬骨と異なり，保存状態が他の出土骨と同様な様 相を示すことより縄文時代のものと思われる」とされ た.しかし，1977～78 年頃，木戸作遺跡の骨資料を実 見した松浦秀治（私信）に上れば，骨の保存状態は一様 でなく, 肉眼観察からは, 第 2 貝塚出土のウマ骨が他 の縄文時代の獣骨と同様であり, 第 5 貝塚出土のウマ骨 はそれらと異なる，という新旧判定を下すことは難しか ったという。また，第 2 貝塚はかなり急な斜面に堆積 した貝塚であり，一部に摫乱を受けている箇所もみられ る(郷田・栗本，1979），第 2 貝塚出土ウマ資料につい ても, いずれ理化学分析を行う必要があろう。

\section{III. 分 析 資 料}

本研究においては, 東京大学総合研究資料館に一時保 管されていた木戸作遺跡第 5 貝塚出土のニホンジカ資 料の中から中手骨 1 点, 中足骨 8 点, それに第 2 貝塚 出土ニホンジカ中足骨 1 点の計 10 点をフッ素分析に供 した.

\section{IV. 分 析 方 法}

\section{1. 試 料 調 製}

骨体 (幹) 緻密質の外表面から内表面に至る小横断片 を切り出し, 外表面に付着する異物を除去した後, メノ ウの乳鉢を用いて均一な微細粉にする. 異物の付着がな い資料部位については, 歯科用ドリルで外表面から内表 面に至る骨粉末試料を採取し, 乳鉢でさらに微細化す る.

\section{2. 使 用 機 器}

コーニング $\mathrm{M}-250$ 型ディジタル $\mathrm{pH} /$ イオンアナライ ザー (0.1 mV 目盛), オリオン 94-09 型フッ素イオン 電極, 岩城硝子 IW 109 型カロメル比較電極.

\section{3. 試薬 調 製}

\section{a) 緩 衝 液}

クエン酸ナトリウム 2 水和物 $147 \mathrm{~g}$ と酢酸ナトリウ 厶 3 水和物 $10.2 \mathrm{~g}$ を, $1 \mathrm{M} \mathrm{KOH} 250 \mathrm{ml}$ と適量の蒸留 水を加えたものに溶解し, 室温に戻した後, 蒸留水を加 えて $1 l$ 定容とする.

\section{b) 標準溶液}

$1 \mathrm{ppm} \mathrm{F}-2.5 \mathrm{ppm} \mathrm{F}^{-}, 10 \mathrm{ppm} \mathrm{F}^{-}$の 3 種の濃度の 標準溶液を以下に従って用意する.

3 つの $30 \mathrm{ml}$ ビーカーに, 各々約 $15 \mathrm{mg}$ のヒドロキ シアパタイト(生化学工業)を取り, $1 \mathrm{M} \mathrm{HCl} 5 \mathrm{ml}$ に溶 解した後, フッ素を各々 $4 \mathrm{ppm}, 10 \mathrm{ppm}, 40 \mathrm{ppm}$ 含有 する $\mathrm{NaF}$ 溶液 $5 \mathrm{ml}$ を加え, さらに上記の緩衝液 $10 \mathrm{ml}$ を混合する.

\section{4. 測 定 操 作}

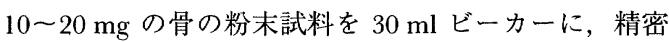
に $( \pm 0.05 \mathrm{mg})$ 量り取り, $1 \mathrm{M} \mathrm{HCl} 5 \mathrm{ml}$ に溶解した後, 蒸留水 $5 \mathrm{ml}$ と緩衝液 $10 \mathrm{ml}$ を加える.この緩衝液は, すべての試料溶液や標準溶液における全イオン強度と $\mathrm{pH}$ を実質的に同一とするために添加する. マグネティ ック・スターラーで溶液を攪拌しながら 2 本の電極を浸 漬し，平衝状態に達した後の電極電位を記録する。ま た, 各試料溶液の温度も測定する $\left(0.1^{\circ} \mathrm{C}\right.$ 単位).

3 点の標準溶液で作成した検量線（式）から試料溶液 のフッ素濃度を求め, 溶解した粉末試料の量を基に, 骨 
試料のフッ素含量を算出する.

電極電位は温度によって変化し, 長期日の使用中には 徐々に変動するので, フッ素濃度の算出には一連の測定 ごとに試料溶液とほほ同一温度 $\left( \pm 0.2^{\circ} \mathrm{G}\right)$ の標準溶液 によって，分析当日新たに作成された検量線を用いる.

なお，この方法で得られる骨粉末試料のフッ素含量測 定值の再現精度は, C. V. (標準偏差/平均) にして 0.010 0.013 である (松浦, 1991).

以上のイオン電極を用いた骨中フッ素の分析法につい ては, Matsu'ura(1981)および松浦（1991）に詳しい。

\section{V. 分析結果と考察}

まず，下田(1979)による木戸作遺跡出土哺乳動物骨 8 点のフッ素分析值を表 1 に示す.この表から, ウマ骨 以外の 7 点の試料が示すフッ素含量は $0.14 \sim 0.40 \%$ の 範囲をとり, 平均 $0.30 \%$, 標準偏差 $0.08 \%$ であること がわかる.これに対して，ウマ骨の示すフッ素含量は $0.07 \%$ と，かなり低い值であった（表 1). 下田(1979） はこの結果について, ウマは「より新しい骨の混入か, あるいは出土状況の相違（貝類の存在の仕方）が考えら れるので, 年代の推定のデーターから外しておくのが適 当とおもわれる」(p. 491)とし, 他の木戸作遺跡出土骨 のフッ素含量を既存のデータから作成した“関係曲線” に合わせると，この貝層の年代は执よそ 4,000 年前にあ たると述べている.

次に，本研究において行った木戸作遺跡出土哺乳動物 骨資料 10 点のフッ素分析結果を表 2 に示す.これら 10 点が示すフッ素含量は $0.141 \sim 0.415 \%$ の範囲をと り, 平均 $0.313 \%$, 標準偏差 $0.094 \%$ であった。これ は, 前述の下田(1979)によるウマ以外の7点が示した フッ素含量值に極めて近似する。また，これらの値は過 去に報告されているデー夕(浜口・立本, 1950 ; Tanabe and Watanabe, 1968 ; 近藤ほか, 1991）および著者 の手元にある未発表データと比較して, 関東地方におけ る縄文時代後期の骨のフッ素含量として矛盾のない值で ある.

ここで, 前述の下田(1979)の 7 点のデータに, 本研 究による 10 点のデータを加えた計 17 点の資料につい て計算すると, 平均 $0.30 \%$, 標準偏差 $0.09 \%$ が得られ た. ウマ骨 1 点の示す $0.07 \%$ という值は,これら 17 点の示寸範囲には入らず, やはり 1 点のみ目立って低 い值といえる.

貝塚などにおいて，周囲を貝類に密に取り囲まれて保 存されていた硬い骨などの場合には, 多量の炭酸カルシ ウムが土壤に含まれるフッ化物の浸透を阻害するため,
表 1 木戸作遺跡出土哺乳動物骨のフッ素含量(下田, 1979 による)

\begin{tabular}{cllll}
\hline No. & \multicolumn{1}{c}{ 資料 } & & 出土地点 & F\% \\
\hline 1 & ウマ & 脛骨 & 第 5 貝塚 & 0.07 \\
7 & ニホンジカ & 上腕骨 & 第 5 貝塚 & 0.14 \\
5 & イノシシ & 大腿骨 & 第 4 貝塚 & 0.28 \\
3 & イノシシ & 大腿骨 & 第 5 貝塚 & 0.28 \\
4 & ニホンジカ & 脛骨 & 第 2 貝塚 & 0.32 \\
8 & ニホンジカ & 上腕骨 & 第 5 貝塚 & 0.32 \\
2 & イノシシ & 大腿骨 & 第 5 具塚 & 0.35 \\
6 & ニホンジカ & 脛骨 & 第 2 具塚 & 0.40 \\
\hline
\end{tabular}

ウマを除く 7 点の $\mathrm{F} \%$ については, mean =0.30, S. D.= 0.08. 試料番号は下田(1979)による.

表 2 本研究による木戸作遺跡出土哺乳動物骨のフッ素 分析結果

\begin{tabular}{|c|c|c|c|c|c|}
\hline \multicolumn{3}{|c|}{ 資料 } & 出土地点 & $\begin{array}{c}\text { 緻密質厚 } \\
(\mathrm{mm})\end{array}$ & $\mathrm{F} \%$ \\
\hline KS- 4 & ニホンジカ & 中足骨 & 第 5 貝塚 & 3.9 & 0.141 \\
\hline KS- 3 & ニホンジカ & 中手骨 & 第 5 貝塚 & 3.4 & 0.208 \\
\hline KS- 6 & ニホンジカ & 中足骨 & 第 5 貝塚 & 3.5 & 0.234 \\
\hline KS- 9 & ニホンジカ & 中足骨 & 第 5 貝塚 & 5.0 & 0.281 \\
\hline $\mathrm{KS}-10$ & ニホンジカ & 中足骨 & 第 5 貝塚 & 5.4 & 0.318 \\
\hline KS- 2 & ニホンジカ & 中足骨 & 第 2 貝塚 & 8.0 & 0.371 \\
\hline KS- 7 & ニホンジカ & 中足骨 & 第 5 貝塚 & 5.0 & 0.376 \\
\hline KS- 5 & ニホンジカ & 中足骨 & 第 5 貝塚 & 4.3 & 0.383 \\
\hline KS- 8 & ニホンジカ & 中足骨 & 第 5 貝塚 & 4.4 & 0.404 \\
\hline KS-11 & ニホンジカ & 中足骨 & 第 5 貝塚 & 5.4 & 0.415 \\
\hline
\end{tabular}

$\mathbf{F} \%$ mean $=0.313$, S. D. $=0.094$

骨におけるフッ素量の増加速度が相対的に低くなること (Oakley, 1963；下田・北村，1975；下田，1979）も想定 されるが，本遺跡出土骨資料を実見した松浦秀治（私 信）によれば，ウマ遺存体が他の獣骨と較へてて特に周囲 に貝類の多い環境に埋存されていたことを示す徴証は観 察されなかったというので, 低フッ素含量を出土状況の 相違によるとする根拠は今のところない.

したがって，木戸作第 5 貝塚出土のウマ遺存体は， 他の動物骨と同時代のものとは考え難く，後世において 縄文貝塚内へ混入した，より新しい時代のものであると 考えられる.

\section{VI. 結 語}

木戸作遺跡第 5 貝塚の縄文時代後期初頭の遺物を包 含する貝層から出土したウマの遺存体について, 下田 
（1979）による本遺跡出土の哺乳動物骨の化学分析の結果 に，本研究による分析データを加えて，フッ素含量に基 づく骨の相対年代判定を試みたところ，このウマ骨は縄 文時代の遺物ではなく，後世のものと考えられた．理化 学分析を用いたこれに類する判定例が現在増えつつあ ク,「縄文馬」の存在については慎重に扱う必要のある ことが今回の研究でも指摘できた.

謝辞 本研究は，㧍茶の水女子大学松浦秀治助教授の ご指導の下に行われた．松浦助教授からは適切なご指示 や資料に関する様々な情報を賜った。また，本研究にお いて，木戸作遺跡出土のウマにフッ素年代判定法が適用 できたのは，故下田信男先生がこの遺跡のウマ資料に関 する貴重なフッ素分析データを遺して下さったお蔭であ る．以上の方々に，ここに謹んで感謝の意を表したい．

\section{引用 文 献}

江坂輝弥（1990）午歳に因み 縄文時代の馬雑感. 考古学 ジャーナル, $314: 3$

郷田良一・栗本佳弘（1979）縄文時代の貝塚と遺物。千葉 県文化財センター編「千葉県南部ニュータウン $7 」$ : 38-357

浜口 博・立本光信 $(1950)$ 人骨の弗素含量. 人類学雑 誌, $61: 51-54$

長谷部言人（1943）日本石器時代馬の一新種に就いて。人 類学雑誌, $58: 1-2$

林田重幸（1978）日本在来馬の系統に関する研究. $180 p$, 日本中央競馬会

樋口清之（1959）日本食物史．295p，柴田書店

加茂儀一（1973）家畜文化史. 1,058p, 法政大学出版局

国分直一（1992）日本文化の古層一列島の地理的位相と民 族文化一. $250 \mathrm{p}$ ，第一書房

近藤 恵・松浦秀治・松井 章・金山喜昭（1991）野田市 大崎貝塚縄文後期貝層出土ウマ遺残のフッ素年代判定一 縄文時代にウマはいたか. 人類学雑誌，99：93-99

近藤 恵 - 松浦秀治 - 中井信之 - 中村俊夫 · 松井 章 （1992）出水貝塚縄文後期貝層出土ウマ遺存体の年代学的 研究. 考古学と自然科学, $26: 61-71$

松浦秀治（1976）荒屋敷貝塚出土獣骨のウランについて, 千葉県文化財センター編「千葉県荒屋敷貝塚一貝塚外縁 部遺構確認調査報告一」:70-75

松浦秀治（1978）築地台貝塚出土獣骨のウラン分析. 千葉 県文化財センター編「築地台貝塚・平山古墳」：127-129

Matsu'ura, S. (1981) Determination of fluorine in fossil bone with an ion-selective electrode. Bulletin of the National Science Museum, Tokyo, Ser. D (Anthropology), 7: 7-16
松浦秀治（1984）フッ素年代判定法と古人骨の編年．日本 人類学会編「人類学一その多様な発展」: 46-50, 日経サ イエンス

松浦秀治(1991)イオン電極を用いた骨中のフッ素の定量. 国立歴史民俗博物館研究報告, $29: 235-244$

松井 章 (1991) 家音と牧一馬の生産. 石野博信ほか編 「古墳時代の研究，第 4 巻 生産と流通 I」：105-119, 雄 山閣出版

松井 章（1992）動物遺存体からみた馬の起源と普及.「馬 具大鑑 1 巻」: 34-44, 馬事財団

最上 宏 (1957) 日本食糧史考, 上巻. $625 p$ (自費出版) 直良信夫 (1971) 日本および東アジア発見の馬歯馬骨. 202p, 日本中央競馬会

西中川 駿 -上村俊雄 - 松元光春 (1989) 古代遺跡出土骨 からみたわが国の牛, 馬の起源, 系統に関する研究.

$95 \mathrm{p}$, 昭和 63 年度文部省科学研究費補助金 (一般研究 B) 研究成果報告書

西中川 駿・本田道輝 - 松元光春 (1991) 古代遺跡出土骨 からみたわが国の牛，馬の渡来時期とその経路に関する 研究. $197 \mathrm{p}$, 平成 2 年度文部省科学研究費補助金 (一般 研究 B）研究成果報告書

野澤 謙（1983）日本の家畜とその系統．佐々木高明編著 「日本農耕文化の源流」:221-242, 日本放送出版協会

Oakley, K. P. (1963) Fluorine, uranium, and nitrogen dating of bone. E. Pyddoke (ed.) The Scientist and Archaeology. 111-119, J. M. Dent \& Sons Ltd.

Oakley, K. P. (1980) Relative dating of the fossil hominids of Europe. Bulletin of the British Museum (Natural History), Geology, 34 : 1-63

大給 尹 (1934) 日本石器時代陸産動物質食料. 史前学雑 誌, $6: 29-43$

佐原 畺（1986）騎馬民族は王朝をたてなかった。埴原和 郎編著「日本人誕生」：127-162，集英社

酒詰仲男 (1961) 日本縄文石器時代食料総説. 338p, 土曜 会

芝田清吾 (1969) $)^{\circ}$ 日本古代家畜史の研究. 293p, 学術書出 版会

下田信男（1979）木戸作貝塚から出土した骨のフッ素およ びマンガン含量と年代との関係. 千葉県文化財センター 編「千葉県南部ニュータウン 7」:489-492

下田信男・北村泰子（1975）骨の相対年代決定法としての フッ素法とマンガン法の比較. 北海道考古学, $11: 1-8$

諏訪 元 - 山田 格·阿部修二 (1979) 爬虫類, 鳥類, 哺 乳類遺体. 千葉県文化財センター編「千葉県南部ニュー タウン 7$\lrcorner: 457-467$

Tanabe, G. and Watanabe, N. (1968) Dating fossil bones from Japan by means of X-ray diffraction pattern. Journal of the Faculty of Science, University of Tokyo, Sec. V, 3 : $199-216$

M. Kondo : Reassessment of the Age of Horse Remains from Late Jomon Shell-bearing Beds at the Kidosaku Site in Chiba City by the Fluorine Dating Method 